\title{
高温における低炭素鋼の引張圧縮疲労変形*
}

\author{
河本 実林田中道七林三木美昌林
}

\section{Axial Fatigue Creep Test of Low Carbon Steel at Elevated Temperatures}

\author{
by \\ Minoru Kawamoto, Tsuneshichi Tanaka and \\ (Kyoto University) \\ Yoshimasa MiKI \\ (Yawata Iron \& Steel Co., Ltd)
}

\begin{abstract}
Previously, some of the present authors conducted experiments on the fatigue creep of various kinds of steel and brass under bending, torsional and axial stress at room temperature, and clarified various features of the fatigue creep of these materials.

This report is on our study concerning the fatigue creep of $0.21 \% \mathrm{C}$ carbon steel at a temperature of $300^{\circ} \mathrm{C}$ and $500^{\circ} \mathrm{C}$, for which a newly devised axial fatigue testing machine for high temperature tests was used.

Results obtained were as follows: At $300^{\circ} \mathrm{C}$, a fatigue creep strain occurred to the specimen increases considerably at the early stages of fatigue, when it is subjected to a combined mean and alternating stress, and, in subsequent repetitions of stress cycles, a slight increase of strain can be observed. But the general feature of fatigue creep strain is similar to that of this material at a room temperature. Namely, the fatigue creep strain is larger than the static creep strain at the same temperature, if the comparison is made under the same maximum stress both in fatigue and static creep tests, and the fatigue creep limit takes substantially the same value of yield point in the static test at this temperature.

At $500^{\circ} \mathrm{C}$, the general feature of fatigue creep strain essentially differs from that at $300^{\circ} \mathrm{C}$ and a room temperature. The fatigue creep strain at this temperature increases gradually with repetitions of stress cycles, and we can observe a remarkable increase of strain in the final stage of fatigue, except when the mean stress is very low. Besides, the fatigue creep strain is smaller than the static creep strain at the same temperature and under the same maximum stress, contrary to the above tendency noticed at $300^{\circ} \mathrm{C}$ and a room temperature. These iphenomena seemed to be resulted from so-called time effect which is recognized at high temperature tests.
\end{abstract}

(Received Jul. 31, 1959)

\section{1. 緒}

\section{言}

一般に材料は, 平均応力をともなう繰返応力を受け た場合，耐久限度以下の応力においても，いちじるし い永久変形を生ずる．したがって，材料がこの種の応 力を受ける場合には，耐久限度のみならず，このよう な永久変形を生じない応力の範囲を明確にすることが 当然必要である.

この点に関して, 著者らの一人は,ささに数種類の 鋼について，曲げおよびねじり繰返応力のもとで生ず る疲労变形に関する研究を行ない, また, 前報におい ては， $0 \cdot 21 \% \mathrm{C}$ 炭素鋼拈よび $6: 4$ 黄銅について, 引

* 原稿受付 昭和 34 年 7 月 31 日

** 正員 京都大学工学部

**** 八幡製鉄株式会社八幡製鉄所
張圧縮応力のもとにおける疲労変形に関する研究を行 なった.

これらの研究の結果, 常温においては, 平均応力を ともなう繰返応力を受けた場合に, 材料に生ずる疲労 变形は, 最大応力で比較した場合, つねに静応力のも とにおける変形よりも大きく,また，静試験において， 明瞭な降伏点を有する材料では, 疲労による降伏限は, 静応力のもとにおける降伏点と一致するが，これに対 して, 明膫な降伏点を示さない材料では, 一定の永久 变形を生じる応力は, 繰返応力を伴う場合は, 静応力 のみの場合に比べてかなり低下することを明らかにし た.

さらに, 高温において, 材料がこの種の応力を受け た場合どのような变形挙動を示すかを明らかにする 
ために, 著者らはさきに, 新しい高温引張圧縮疲労試 験機の試作を行なったが，その構造および特性につい ては，すでに報告したとおりである。

本研究においては，うえの試験機を用いて，0.21\% $\mathrm{C}$ 炭素鋼の $300^{\circ} \mathrm{C}$ おび $500^{\circ} \mathrm{C}$ の温度における高温引 張圧縮疲労試験を実施し, 応力振幅および平均応力を 種々に変えた場合に，材料に生ずる疲労変形ならびに 疲労強度に関する実験を行なった。また，高温におい ては, 静応力のもとにおけるクリープが当然問題にな るのであるが，うえの温度におけるクリーブ試験も同 時に行ない，こうして得られた結果およびさきに行な った常温における実験結果をあわせて考察を加えた。

\section{2. 実験材料ならびに実験方法}

実験に使用した $0 \cdot 21 \% \mathrm{C}$ 炭素鋼の化学成分を Table 1 に，熱処理および常温における機械的性質を Table 2 に示した。

Fig. 1 は試験片の形状および寸法であって, 熱処理 後機械仕上げした.

使用した高温引張圧縮疲労試験機および变形測定装 置，試験片加熱用電気炉，温度測定装置などの構造な らびに特性の詳細については，すでに報告したのでこ こでは省略する。

試験温度は $300^{\circ} \mathrm{C}$ および $500^{\circ} \mathrm{C}$ の 2 種類とし， 300 ${ }^{\circ} \mathrm{C}$ においては，応力振幅 $\sigma_{a}$ をほぼ $16 \mathrm{~kg} / \mathrm{mm}^{2}$ およ び $11 \mathrm{~kg} / \mathrm{mm}^{2}$ として, 平均応力 $\sigma_{m}$ を種々に変えた 場合, $500^{\circ} \mathrm{C}$ においては, 応力振幅をほぼ $15 \mathrm{~kg} / \mathrm{mm}^{2}$ および $11 \mathrm{~kg} / \mathrm{mm}^{2}$ として平均応力を種々に変えた場 合について, 疲労試験を行なった。なお，その場合の 応力繰返速度は，すべて $800 \mathrm{cpm}$ とした．以上のほか に,さらに $300^{\circ} \mathrm{C}$ およ゙ $500^{\circ} \mathrm{C}$ の温度において, 疲労 試験に相当した時間内でのクリープ試験を行ない，こ れらのすべての実験に際して, 試験中, 試験片に生ず る伸びの測定を行なった。

なお，伸びの測定は，Fig. 1 に示した試験片の段つ きの部分(直径 $8 \mathrm{~mm}$ の部分)に金具を取りつけ，これ

Table 1 Chemical composition of material

\begin{tabular}{|c|c|c|c|c|c|c|}
\hline \multirow[t]{2}{*}{ Material } & \multirow[t]{2}{*}{ Symbol } & \multicolumn{5}{|c|}{$\begin{array}{c}\text { Chemical composition } \\
(\%)\end{array}$} \\
\hline & & $\mathrm{C}$ & $\mathrm{Si}$ & $\mathrm{Mn}$ & $\mathrm{P}$ & $\mathrm{S}$ \\
\hline Mild steel & ヒ 2796 & 0.21 & $0 \cdot 25$ & 0.58 & 0.030 & 0.042 \\
\hline
\end{tabular}

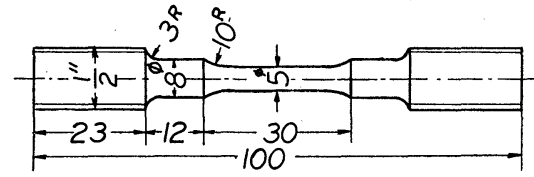

Fig. 1 Test specimen

より引出し棒によって, 試験片の伸びを電気炉の外に 取り出して行なっているために, 測定した伸びの值に は, 平行部分両端の丸味部分, および金具を取りつけ た段つきの部分の伸びが含まれている．しかしここ では段つきの部分の伸びは無視し, 丸味部分について は, 応力集中を無視して, 弾性学的に, この部分を平 行部分と同一の直径に置き变えた場合の長さを計算し て，これを平行部分に加えたものをもって，有効標点 間距離とし, 伸びの測定值をこの距離で除して, ひず みを救めた。 また，この值より永久ひずみ $\varepsilon_{p}$ を求 めるには, ひずみ測定時の応力を, 各温度における弾 性係数で除した值を, うえの

\section{3. 実験結果ならびにその考察}

\section{（a）永久ひずみ-繰返数線図 $\left(\varepsilon_{p}-\boldsymbol{N}\right.$ 線図}

$0 \cdot 21 \% \mathrm{C}$ 炭素鋼について，うえに述べたような方法 を用いて, 疲労試験およびクリープ試験を行ない, 試 験片に生ずる永久ひずみを測定した結果を，Fig. 4〜 6, および Fig. 7〜9 に示す.このうち Fig. 4, Fig. 5 および Fig. 7, Fig. 8 は，それぞれ $300^{\circ} \mathrm{C}$ おび 500' ${ }^{\circ} \mathrm{C}$ の温度において, 疲労試験を行なった場合に，生 ずる永久ひずみの測定結果であり，Fig. 6 および Fig. 9 は，それぞれの温度において，応力振幅 $\sigma_{a}=0$, す なわち, 静荷重として平均応力 $\sigma_{m}$ のみを加えたクリ 一ブ試験に対する結果である。いずれも縦軸には，前 節で述べたような方法を用いて求めた永久ひずみ $\varepsilon_{p}$ を\%でとり，横軸には，応力繰返数 $N を$ 対数目もりで とって示したもので, 応力振幅 $\sigma_{a}$ をほぼ一定とし, 平均応力 $\sigma_{m}$ を種々に変えた場合について図示してあ る.ただし, Fig. 6 および Fig. 9 のクリープ試験に おいては，横軸は一般に時間をとって示すべきである が，ここでは疲労試験の結果との比較を容易にするた め, 繰返速度 $800 \mathrm{cpm}$ として換算した，相当繰返数 $N$ を横軸にとってある。

Fig. 2 および Fig. 3 はうえの実験結果と比較する ために，さきに報告した，常温における実験結果の中

Table 2 Heat treatment and mechanical properties of material

\begin{tabular}{|c|c|c|c|c|c|c|c|c|}
\hline Material & Symbol & Heat treatment & \begin{tabular}{|} 
Upper yield \\
point \\
$\sigma$ so \\
$\left(\mathrm{kg} / \mathrm{mm}^{2}\right)$
\end{tabular} & $\mid \begin{array}{c}\text { Lower yield } \\
\text { point } \\
\sigma s u \\
\left(\mathrm{~kg} / \mathrm{mm}^{2}\right)\end{array}$ & $\begin{array}{c}\text { Ultimate } \\
\text { strength } \\
\sigma_{B} \\
\left(\mathrm{~kg} / \mathrm{mm}^{2}\right) \\
\end{array}$ & \begin{tabular}{|c|} 
Breaking \\
strength on \\
final area \\
$\sigma_{T}$ \\
$\left(\mathrm{~kg} / \mathrm{mm}^{2}\right)$
\end{tabular} & $\begin{array}{c}\text { Elongation } \\
\varphi \\
(\%)\end{array}$ & $\begin{array}{c}\text { Reduction } \\
\text { of area } \\
\psi \\
(\%)\end{array}$ \\
\hline Mild steel & ヒ 2796 & $875^{\circ} \mathrm{C}$ 1hr anneal & $33 \cdot 4$ & $28 \cdot 7$ & $51 \cdot 1$ & $87 \cdot 1$ & $38 \cdot 4$ & $54 \cdot 0$ \\
\hline
\end{tabular}




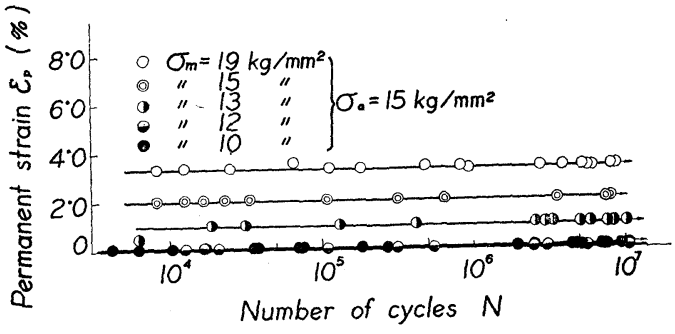

Fig. $2 \varepsilon_{p}-N$ diagram at room temperature

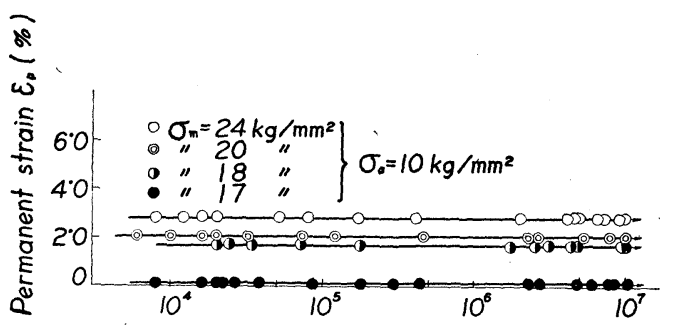

Number of cycles $N$

Fig. $3 \varepsilon_{p}-N$ diagram at room temperature

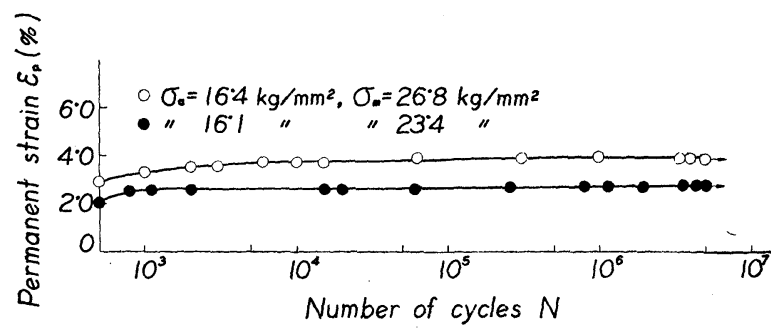

Fig. $4 \varepsilon_{p}-N$ diagram at $300^{\circ} \mathrm{C}\left(\sigma_{a} \cong 16 \mathrm{~kg} / \mathrm{mm}^{2}\right)$

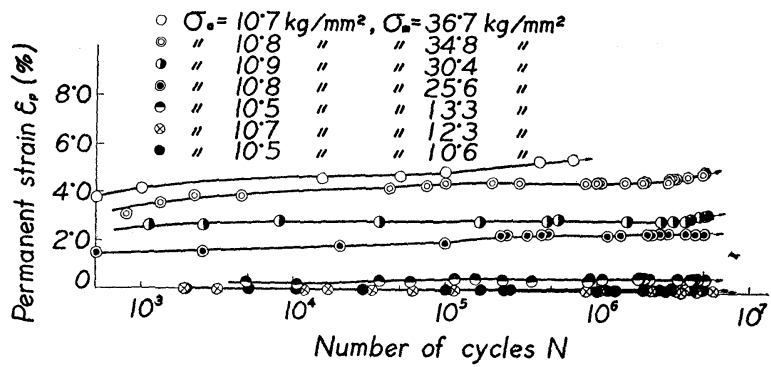

Fig. $5 \varepsilon_{p}-N$ diagram at $300^{\circ} \mathrm{C}\left(\sigma_{a} \cong 11 \mathrm{~kg} / \mathrm{mm}^{2}\right)$

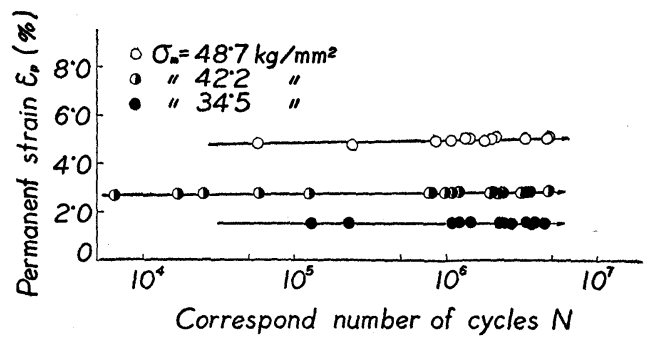

Fig. $6 \varepsilon_{p^{-}} N$ diagram at $300^{\circ} \mathrm{C}\left(\sigma_{a}=0\right)$

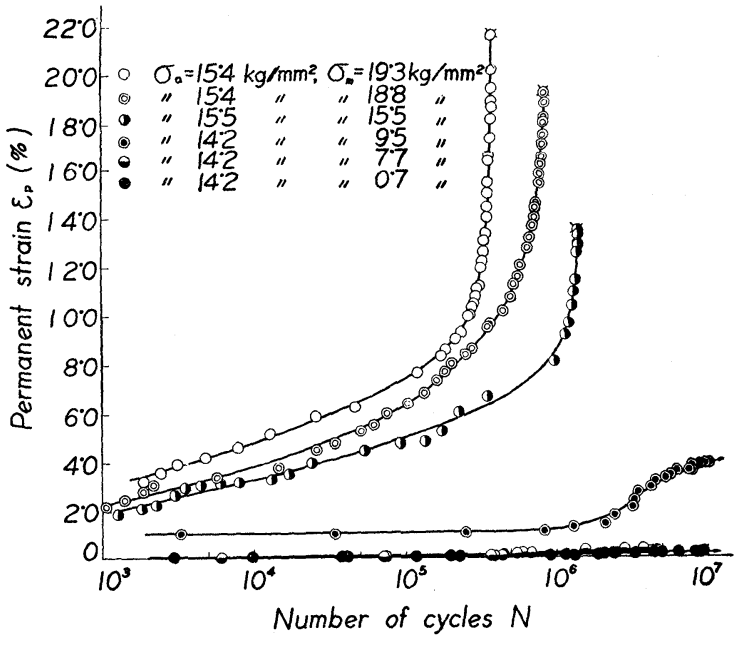

Fig. $7 \varepsilon_{p}-N$ diagram at $500^{\circ} \mathrm{C}\left(\sigma_{a} \cong 15 \mathrm{~kg} / \mathrm{mm}^{2}\right)$

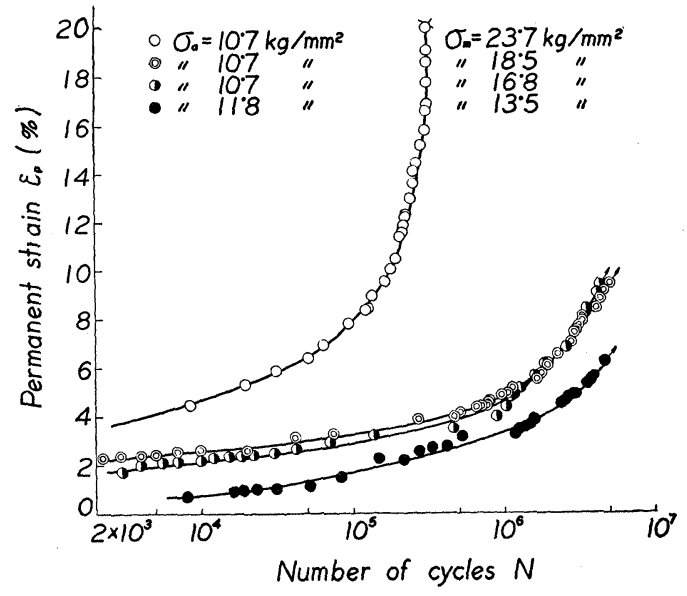

Fig. $8 \varepsilon_{p}-N$ diagram at $500^{\circ} \mathrm{C}\left(\sigma_{a} \cong 11 \mathrm{~kg} / \mathrm{mm}^{2}\right)$

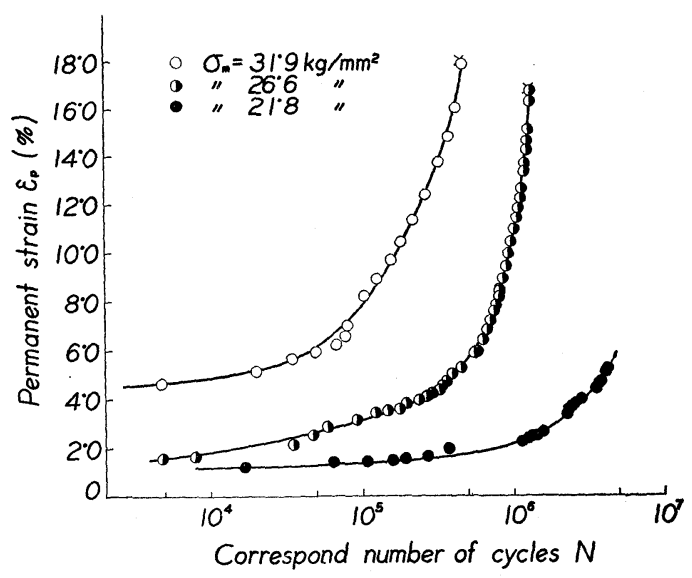

Fig. $9 \varepsilon_{p}-N$ diagram at $500^{\circ} \mathrm{C}\left(\sigma_{a}=0\right)$ 
Table 3 Mechanical properties of material used for test at room temperature

\begin{tabular}{|c|c|c|c|c|c|}
\hline $\begin{array}{c}\text { Upper } \\
\text { yield } \\
\text { point } \\
\sigma s o \\
\left(\mathrm{~kg} / \mathrm{mm}^{2}\right) \\
\end{array}$ & $\begin{array}{c}\text { Lower } \\
\text { yield } \\
\text { point } \\
\sigma s u \\
\left(\mathrm{~kg} / \mathrm{mm}^{2}\right)\end{array}$ & $\begin{array}{c}\text { Ultimate } \\
\text { strength } \\
\sigma_{B} \\
\left(\mathrm{~kg} / \mathrm{mm}^{2}\right)\end{array}$ & $\begin{array}{c}\text { Breaking } \\
\text { strength } \\
\text { on final } \\
\text { area } \\
\sigma T \\
\left(\mathrm{~kg} / \mathrm{mm}^{2}\right)\end{array}$ & $\begin{array}{c}\text { Elon- } \\
\text { gation } \\
\varphi \\
(\%) \\
\end{array}$ & $\begin{array}{c}\text { Reduc- } \\
\text { tion } \\
\text { of area } \\
\psi \\
(\%)\end{array}$ \\
\hline $28 \cdot 7$ & $26 \cdot 8$ & $52 \cdot 1$ & $87 \cdot 9$ & $28 \cdot 9$ & $55 \cdot 0$ \\
\hline
\end{tabular}

から, 応力振幅をそれぞれ, $15 \mathrm{~kg} / \mathrm{mm}^{2}$ および $10 \mathrm{~kg}$ $/ \mathrm{mm}^{2}$ として, 平均応力を種々に变えた場合の実験結 果を示したもので，縦軸には，やはり永久ひずみ $\varepsilon_{p}$ を\%でとり，横軸に繰返数 $N$ を対数目もりでとって示 したものである，ただし，この常温における試験は

Haigh 式引張圧縮疲労試験機を用いて行なったもので, その際の応力繰返速度は約 $1800 \mathrm{cpm}$ であった．また， 常温において用いた材料の化学成分および熱処理は本 実験におけると同一であるが，機械的性質は少しく異 なるので，それを Table 3 に示してある.

以上の実験結果を比較してみると, まず常温におい ては, Fig. 2 および Fig. 3 にみるように, 試験片に 生ずる永久ひずみ $\varepsilon_{p}$ は, 繰返数のごく初期に起り,

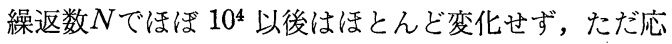
力の高い場合にのみ，ごくわずかの増加がみられる.

つぎに, $300^{\circ} \mathrm{C}$ の温度においては，Fig. 4 および

Fig. 5 をみると, 応力振幅を, 常温におけるとほぼ同 じ, $16 \mathrm{~kg} / \mathrm{mm}^{2}$ および $11 \mathrm{~kg} / \mathrm{mm}^{2}$ として平均応力を 種々に变えた場合に，生ずる永久ひずみ $\varepsilon_{p}$ は，やは り繰返数の初期にいちじるしく起るが, それ以後の繰 返数においても, ゆるやかではあるが, しだいに増加 しており，この点常温の場合と若干異なる傾向がみら

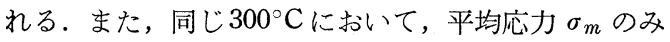
を加えたクリープ試験の結果 Fig. 6 をみると, やは り初期にかなりの永久ひずみを生じているが, その後 の増加は, 同温度の疲労試験における, 永久ひずみの 増加に比べればわずかである。

$500^{\circ} \mathrm{C}$ の温度においては, Fig. 7 および Fig. 8 か らわかるように, 永久ひずみ $\varepsilon_{p}$ の繰返数 $N$ に対する

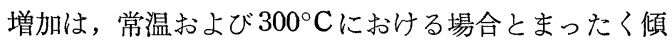
向を異にし, 平均応力のごく小さい場合を除いて,ひ ずみは繰返数とともに，しだいに増加し，破断前にお いて急激な增加を示している。 また，Fig. 9 の同温度 におけるクリープ試験においても, ひずみの増加は疲 労試験における場合とほぼ同様の傾向を示しているこ とがわかる。

（b）応力-永久ひずみ線図 $\left(\sigma_{\max }-\varepsilon_{p}\right.$ 線図 $)$

以上の実験結果から, それぞれの温度における静試 験, クリープ試験および疲学試験において, 試験片に 生ずる永久ひずみと, その際の応力との関係を明らか にするために, 縦軸に, これら 3 種の試験において,
試験片に加えた最大応力 $\sigma_{\max }$ をとり，横軸に永久ひ ずみ $\varepsilon_{p}$ をとって図示すると，Fig. 10, Fig. 11 およ び Fig. 12 ( a ) (b)(c)のようになる.このうち, Fig. 10 および Fig. 11 はそれぞれ常温および $300^{\circ} \mathrm{C}$ の温度に対するもので, 前項に述べたように, 常温に おいては, 繰返数 $N$ がほぼ $10^{4}$ 以後は，ほとんどひず みの増加がみられないこと，および $300^{\circ} \mathrm{Cにおいては，}$ このような繰返数に対しても, 若干ひずみの增加がみ られるのであるが, その程度はわずかであることを考 虑して, いずれも繰返数 $N=10^{6}$ における永久ひずみ $\varepsilon_{p}$ を横軸にとったものである. Fig. 12 (a) (b) およ び(c)は $500^{\circ} \mathrm{C}$ の場合で, この温度においては, 上述 のように, 平均応力の小さい場合を除けば，永久ひず みは繰返数とともにいちじるしく増加するために, 繰

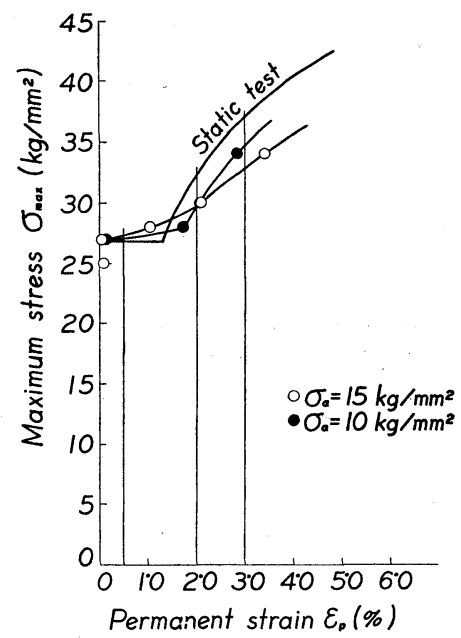

Fig. $10 \sigma_{\max }-\varepsilon_{p}$ diagram at room temperature

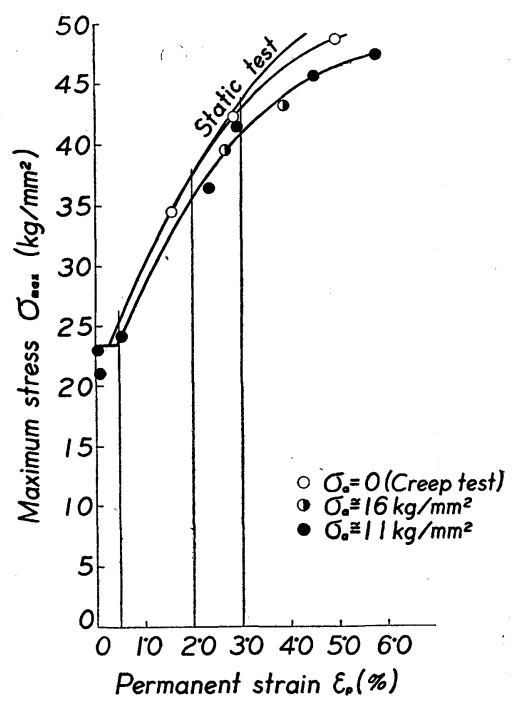

Fig. $11 \sigma_{\max }-\varepsilon_{p}$ diagram at $300^{\circ} \mathrm{C}$ 


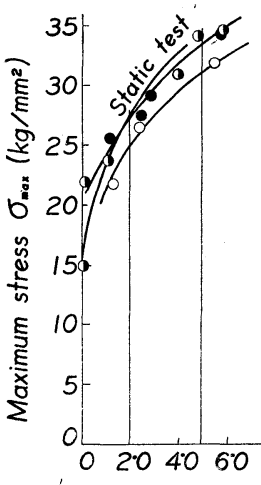

(a) $N=3 \times 10^{4}$

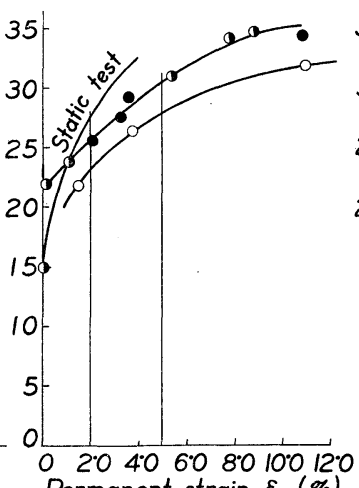

Permanent strain

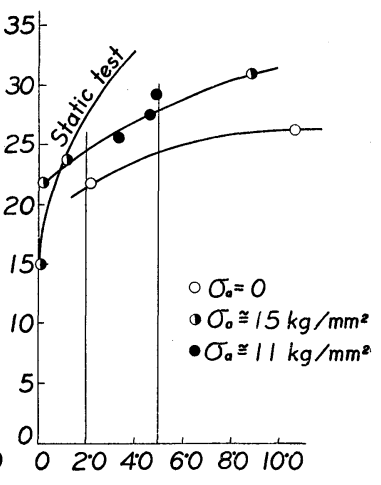

(c) $N=10^{6}$

Fig. $12 \sigma_{\max }-\varepsilon_{p}$ diagram at $500^{\circ} \mathrm{C}$

返数 $N=3 \times 10^{4}, 2 \times 10^{5}$ および $10^{6}$ における永久ひず み $\varepsilon_{p}$ をそれぞれ横軸にとり， $\sigma_{\mathrm{m} a \mathrm{x}}-\varepsilon_{p}$ 線図が繰返数 とともに变化するようすを明らかにしたものである.

これらの図をみると, まず常温においては, 最大応 力で比較した場合, 疲労試験の際に生ずる永久ひずみ は, 静試験において生ずる永久ひずみよりも大きく， またこのように, 静試験において明膫な降伏点を有す る材料に対しては, 疲労による降伏限は, 静試験の場 合に得られる降伏点と一致すること，および応力振幅 が小さくなるに従って, 疲労試験の際の $\sigma_{\max }-\varepsilon_{p}$ 線 図が，静試験におけるそれに近づく傾向があることな どがわかる。

つぎに $300^{\circ} \mathrm{C}$ の温度においては，うえと同様，最大 応力で比較した場合，Fig. 11 より明らかなように， 疲労試験の際に生ずる永久ひずみは, 静応力のみを加 えたクリープ試験において生ずる永久ひずみよりも， つねに大きいことがわかる，また，同図中に示した短 時間の静引張試験結果は, 明膫な降伏点を示している が，いっぼう疲労試験において得られる降伏限も，こ の静試験の際における降伏点と一致することがわかる. なお, Fig. 11 では応力振幅 $\sigma_{a}$ 在活ほ $16 \mathrm{~kg} / \mathrm{mm}^{2}$ お よび $11 \mathrm{~kg} / \mathrm{mm}^{2}$ とした場合に生ずる永久ひずみは， 常温におけるように，応力振幅の差によって明らかな 相違を示していないために同一の曲線で表わしてある.

$500^{\circ} \mathrm{C}$ の温度に打いては，さきにも述べたように， 試験片に生ずる永久ひずみは，応力の繰返数とともに いちじるしく増加する．Fig. 12 (a) (b) および（c) はこの間の $\sigma_{\max }-\varepsilon_{p}$ 線図の变化のもようを示したもの で，応力の低い場合を除けば，静応力のみを与えたク リーブ試験においても, また, 繰返応力をともなう疲 労試験においても，永久ひずみは繰返数とともにいち じるしい增加を示している，またここの温度において は, 常温および $300^{\circ} \mathrm{C}$ の場合と異なり, 最大応力で比 較した場合, 疲労試験の場合に生ずる永久ひずみは,
静応力のみを加えたクリープ試 験において生ずる永久ひずみよ りも，つねに小さいことがわか る。なお，これらの図において も，300 $\mathrm{C}$ におけると同様，応 力振幅をほぼ $15 \mathrm{~kg} / \mathrm{mm}^{2}$ およ び $11 \mathrm{~kg} / \mathrm{mm}^{2}$ とした場合の永 久ひずみには，いちじるしい差 が認められないために一つの曲 線で表わしてある。また，図中 には同温度における短時間の引 張試験結果も參考のためにあわ せ示した。

以上の結果より, $300^{\circ} \mathrm{C}$ にお いて，材料が平均応力ならびに繰返応力を受けた場合 に生ずる永久ひずみの諸特性は，ほぼ常温の場合と同 様の傾向を有していることがわかる．しかし定量的に 比較するならば, $300^{\circ} \mathrm{C}$ における疲労降伏限は, 常温 における疲労降伏限よりも多少低下するにもかかわら ず，ひずみの大きい範囲では，一定の永久ひずみを生 ずる応力は， $300^{\circ} \mathrm{C}$ の温度におけるほうが，常温にお けるよりも逆に高くなっており,この間の関係は, そ れぞれの温度における静試験結果の示す傾向と一致し ている。

ところが， $500^{\circ} \mathrm{C}$ の温度においては，变形の諸特性 はうえにも述べたように，常温および $300^{\circ} \mathrm{C}$ の温度に おいてみられる特性と, まったく傾向を異にしており, とくに，繰返応力を伴う場合に生ずる永久ひずみが， 静応力のみを加えたクリープ試験の際に生ずる永久ひ ずみに比べて小さいことは，この温度において試験片 に生ずるひずみが，応力の作用する時間に関係し，し たがって，最大応力で比較すれば，疲労試験における ほうが，クリープ試験の場合に比べて，高い応力の作 用している時間が短いために, 当然, 生ずる永久ひず みも小さくなるものと考えられる。

(c) 一定の永久ひずみを生ずる応力振幅 $\sigma_{a}$ と平均 応力 $\sigma_{m}$ の関係 $\left(\sigma_{a}-\sigma_{m}\right.$ 線図 $)$

Fig. 13〜15 は Fig. 10〜12 をもとにして，緃軸に 応力振幅 $\sigma_{a}$, 横軸に平均応力 $\sigma_{m}$ をとり, それぞれの 温度において，一定の永久ひずみを生ずる $\sigma_{a}$ および $\sigma_{m}$ の值を図示したもので，Fig. 13 および Fig. 14 に おいては，それぞれ常温および $300^{\circ} \mathrm{C}$ の場合について， Fig. 10 および Fig. 11 におけると同様, 繰返数 $N=$ $10^{6}$ において，試験片に生ずる永久ひずみをとり，そ れぞれ $\varepsilon_{p}=0.5 \%, 2 \%$ および $3 \%$ を生ずる応力の值 を示してある. また, Fig. 15 の $500^{\circ} \mathrm{C}$ の場合につい ては，一定の永久ひずみ $\varepsilon_{p}=2 \%$ および $5 \%$ を生ずる 応力振幅 $\sigma_{a}$ および平均応力 $\sigma_{m}$ を Fig. 12 における 


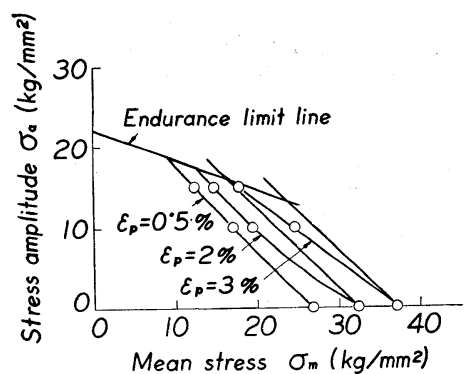

Fig. $13 \sigma_{a^{-} \sigma_{m}}$ diagram for $\varepsilon_{p}=$ const. at room temperature

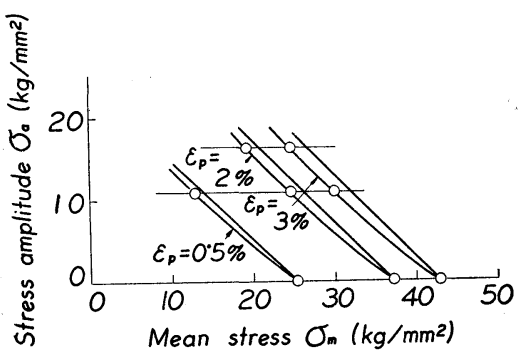

Fig. $14 \sigma_{a^{-}} \sigma_{m}$ diagram for $\varepsilon_{p}=$ const. at $300^{\circ} \mathrm{C}$

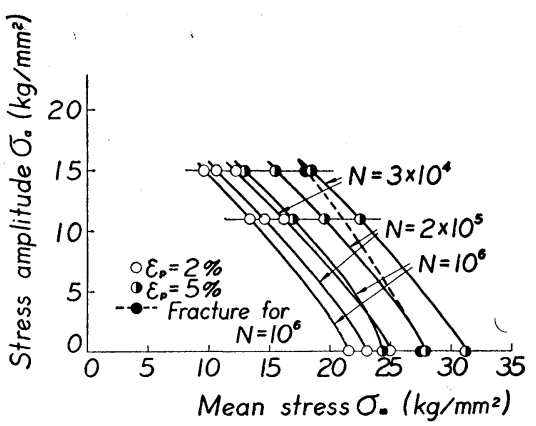

Fig. $15 \sigma_{a^{-}} \sigma_{m}$ diagram for $\varepsilon_{p}=$ const. and fracture at $500^{\circ} \mathrm{C}$

と同様, 3 種類の応力繰返数について図示したもので ある.なお，Fig. 14 および Fig. 15 における横軸上

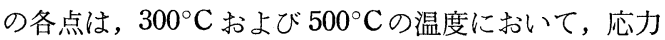
振幅 $\sigma_{a}=0$, すなわちクリープ試験の結果より, 一定 の永久ひずみを生ずる応力の值を図示したものであり， また，Fig. 13 の常温の場合においては，クリープ試 験を行なっていないために, 静試験の結果をもとにし て, 所定の永久ひずみを生ずる応力の值を図示してあ る。また, 同図中には, 常温において得られた耐久限 度線もあわせ示した。

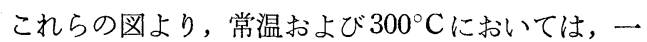
定の永久ひずみ $\varepsilon_{p}$ に対する $\sigma_{a}-\sigma_{m}$ 曲線は, 永久ひず みの值が増すにつれて，しだいに，横軸上の点をとお る $45^{\circ}$ の直線よりも，原点の側にかたよってきており，
このことは前項にも述べたように，疲労試験の際に生 ずる永久ひずみは，静応力のみの場合に生ずる永久ひ ずみよりも大きいことを示しており，また，このかた よりが，常温に比べて, $300^{\circ} \mathrm{C}$ の場合には比較的小さ いのは, Fig. 10 および Fig. 11 を比較した場合，

Fig. 11 の $300^{\circ} \mathrm{C}$ の場合のほうが, 常温に比べて, 疲 労試験の際の $\sigma_{\max }-\varepsilon_{p}$ 線図が, クリープ試験ないしは 静試験の $\sigma-\varepsilon_{p}$ 際の線図に近いことを示すものである。

つぎに Fig. 15 の $500^{\circ} \mathrm{C}$ の場合には，うえと異なっ て，一定の永久ひずみを与える $\sigma_{a}-\sigma_{m}$ 曲線はいずれ の場合においても, 相対応する横軸上の点をとおる $45^{\circ}$ の直線よりも，明らかに右側をとおっていること がわかる。このことは繰り返し述べたように, 疲労試 験の際に生ずる永久ひずみが，静応力のもとで生ずる 永久ひずみよりも逆に少ないことを示すものである. なお，図中の黒丸および破線は，參考のために，応力 繰返数 $N=10^{6}$ で破断する場合の応力振幅 $\sigma_{a}$ 之平均 応力 $\sigma_{m}$ の值を図示したものである。

\section{4. 結}

\section{言}

$0.21 \% \mathrm{C}$ 炭素鋼を用いて, $300^{\circ} \mathrm{C}$ おび $500^{\circ} \mathrm{C}$ の温 度で, 引張圧縮疲労試験およびクリープ試験を行ない, 試験片に生ずる永久ひずみを測定して，さきに求めた 常温における実験結果も含めて考察した結果, つぎの ことが明らかとなった。

$300^{\circ} \mathrm{C}$ の温度においては, 材料が繰返応力ならびに 平均応力を受ける場合に，発生する永久ひずみは，応 力繰返数の初期に急激に起るが, その後の繰返数にお いてもゆるやかな増加がみられる.しかしながら,こ のような応力のもとで生ずる永久ひずみの諸特性は， ほぼ常温における場合と同様の傾向を示している。す なわち, 疲労試験の際に生ずる永久ひずみは, 最大応 力で比較した場合, クリープ試験ないしは静試験の際 に生ずる永久ひずみよりもつねに大きく，また，疲労 降伏限は, 静試験の際に得られる降伏点に一致する.

$500^{\circ} \mathrm{C}$ の温度においては, 常温および $300^{\circ} \mathrm{C}$ の場合 と異なり，永久ひずみは応力繰返数とともにしだいに 増加し, 破断前にはいちじるしい増加を示す。また, 疲労試験の場合に生ずる永久ひずみは, 最大応力で比 較した場合, 静応力のみを与えたクリープ試験におい て生ずる永久ひずみよりもつねに小さく，この点にお いても，常温および $300^{\circ} \mathrm{C}$ の場合に比べてまったく異 なる傾向を示している.

\section{参 考 文 献}

1) 河本実, 西岡邦雄, 材料諎験, 3, 14, 260/265（昭29.5）

2）河本実, 伊藤向, 岩村幸裕, 材料試臥, 5, 31, 217/222（昭31.4）

3) 河本実, 田中道七, 福井洵, 材料試験, 8, 68, 410/414 (昭34.5)

4) 河本実, 田中道七，三木美昌，材料試験，8，68，415/418 (昭34.5) 